\title{
Nucleic Acid Changes in Bacteroids of Rhizobium lupini During Nodule Development
}

\author{
By M. J. DILWORTH AND D. C. WILLIAMS \\ Department of Soil Science and Plant Nutrition, \\ University of Western Australia, Nedlands, Western Australia
}

(Accepted for publication 17 October 1966)

SUMMARY

The nodules of yellow lupin plants (Lupinus luteus L.) increased logarithmically in wet weight, leghaemoglobin and rhizobial numbers. Bacteroids were isolated from such nodules and the changes in concentration of protein, RNA and DNA per organism were followed as a function of nodule age. Six weeks after emergence, DNA and RNA per organism had fallen to $40 \%$ and $13 \%$, respectively, of the values found in the bacteria from 1-week-old nodules. No further changes in RNA and DNA were found after this time. The decreases are discussed with reference to previous reports of loss of nuclear material during bacteroid formation.

\section{INTRODUCTION}

Several investigations of changes in the nuclear material of organisms isolated from the nodules of legumes have been made in an attempt to explain the low viability of such cells on laboratory media (Almon, 1933).

Rautanen \& Saubert (1955), in a chemical study, emphasized the fact that both soybean and cowpea bacteroids contained considerably less nucleic acid than the respective laboratory grown rhizobia, the difference being most marked with soybean organisms. Such differences, however, may be due to changes in composition of the laboratory grown cells with stage of growth.

Various studies with stained material under the light microscope also suggest losses of nuclear material during bacteroid formation. Schaede (1941) noted that bacteroids from Pisum sativum and Vicia faba did not give a Feulgen reaction, while those from lupin gave a diffuse reaction decreasing when the cells underwent digestion. Heumann (1952) showed that pea bacteroids gave a Feulgen reaction from 'nucleoids' in only about $40 \%$ of the cells. Indications that nuclear material was diffuse in bacteroids from young nodules and only appeared as nucleoids later in their development were obtained with fluorescence microscopy (Chizhik, 1959). Bergersen (1955) observed that the amount of nuclear material apparently decreased with nodule age with bacteroids from subterranean clover stained by various nuclear stains.

In bacteroids from soybean, Bergersen (1958) concluded that it was unlikely that cessation of division of the bacteroids was due to lowered nucleic acid content. No significant changes occurred in the total nucleic acid of bacteroids from nodule initiation to maturity, and no differences were found between bacteroids and laboratorygrown cells in their nucleic acid content. Since the methods used do not distinguish 
between RNA and DNA, changes in DNA affecting capacity for division could have been obscured.

Electron microscopy of clover and medic nodules (Dart \& Mercer, 1963) showed that the fibrillar material of the nucleoid region of rod-shaped cells in the infection thread decreased after release into host cells during nodule formation.

The literature cited indicates that definite losses of nuclear material occur during bacteroid formation in legume nodules, though the report of Bergersen (1958) is at variance with other chemical and microscopic evidence. However, whether the nuclear degeneration is accompanied by loss of DNA is still unknown.

\section{METHODS}

Plants. Seeds of Lupinus luteus L. were inoculated with strain of D25 of Rhizobium lupini maintained according to Parker \& Oakley (1963), and sown in the field in sand given the following fertilizer treatment: $1 \mathrm{~g}$. per square foot of a mixture of commercial superphosphate, rock phosphate, $\mathrm{KCl}$ and $\mathrm{MgSO}_{4} \cdot 7 \mathrm{H}_{2} \mathrm{O}$ mixed in a ratio of $2: 4: 2: 1(\mathrm{w} / \mathrm{w})$, and $0.035 \mathrm{~g}$. per square foot of a mixture of commercial $\mathrm{CuSO}_{4} \cdot 5 \mathrm{H}_{2} \mathrm{O}, \mathrm{ZnSO}_{4} .7 \mathrm{H}_{2} \mathrm{O}, \mathrm{Na}_{2} \mathrm{MoO}_{4}$ and $\mathrm{MnSO}_{4} \cdot 4 \mathrm{H}_{2} \mathrm{O}$ mixed in the ratio 2:2:1:2 by weight.

All times are recorded from emergence.

Isolation of bacteroids. The term 'bacteroids' used here refers only to rhizobia obtained from nodules. Bacteroids from lupin nodules rarely exhibit the extreme deformation of shape commonly seen with bacteroids from clover and medic nodules, though they are enlarged compared to laboratory-grown cells.

One week after emergence, nodules were visible only as $1 \mathrm{~mm}$. foci in the root cortex, with no detectable swelling of the root. Lengths of these roots $(2 \mathrm{~cm}$.) were washed and then homogenized in $0.1 \mathrm{M}$-potassium phosphate buffer $(\mathrm{pH} \mathrm{7.1)}$ in a $20 \mathrm{ml}$. Perspex homogenizer and filtered through a sintered glass funnel (porosity 0 ) to remove plant debris. This procedure was only necessary for weeks 1 and 2.

In later weeks, the nodules were large enough to be conveniently removed from the roots. Between weeks 3 and 8 , these were sufficiently soft to be homogenized directly but from week 9 , this was unsatisfactory and the hardened cortex was pared away with a scalpel before homogenizing and filtering.

The filtrate was then centrifuged, first at $300 \mathrm{~g}$ for $5 \mathrm{~min}$. to remove starch grains and plant material, then at $2700 \mathrm{~g}$ for $15 \mathrm{~min}$. to sediment bacteroids. These were washed once with $0 \cdot 1 \mathrm{M}$-phosphate $(\mathrm{pH} \mathrm{7 \cdot 1)}$ and resuspended in the same buffer. All operations after the removal of nodules (or root segments) were performed at $4^{\circ}$.

Counting. Bacteroids were counted under dark-field illumination at a magnification of 400 , in a Hawksley-Thoma counting chamber. A minimum of 1,000 cells was counted at several dilutions.

Estimation of protein and nucleic acids. Soluble cell protein was measured by the biuret method. Bacteroid samples were treated with 2 vols of $5 \%(w / v)$ trichloracetic acid (TCA) and centrifuged. The cells were resuspended in biuret reagent (Dawson, Elliott, Elliott \& Jones, 1959) and colour measured after 30-60 min. at room temperature and a centrifugation at $20,000 \mathrm{~g}$ for $10 \mathrm{~min}$.

Nucleic acids were measured as ribose and deoxyribose, after degradation according to Volkin \& Cohn (1954), but omitting the extractions with organic solvents. Ribose 
was estimated by a modification of the orcinol method (Oliver \& Blumer, 1964) using yeast RNA (type XI, Sigma Chemical Co., St Louis, U.S.A.) as a standard. Deooxyribose was estimated by the diphenylamine reaction (Burton, 1956) using a standard of salmon sperm DNA (California Foundation for Biochemical Research, Los Angeles, U.S.A.) hydrolysed by heating for $15 \mathrm{~min}$. at $70^{\circ}$ in $0.5 \mathrm{~N}$-perchloric acid.

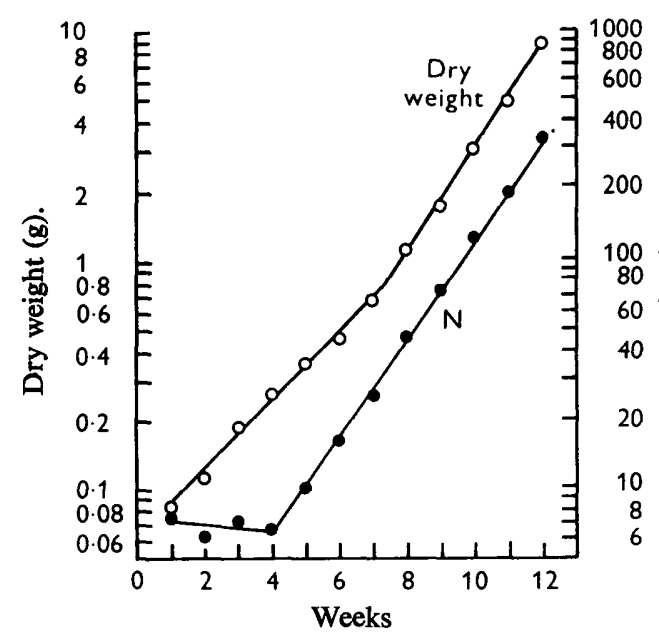

Fig. 1

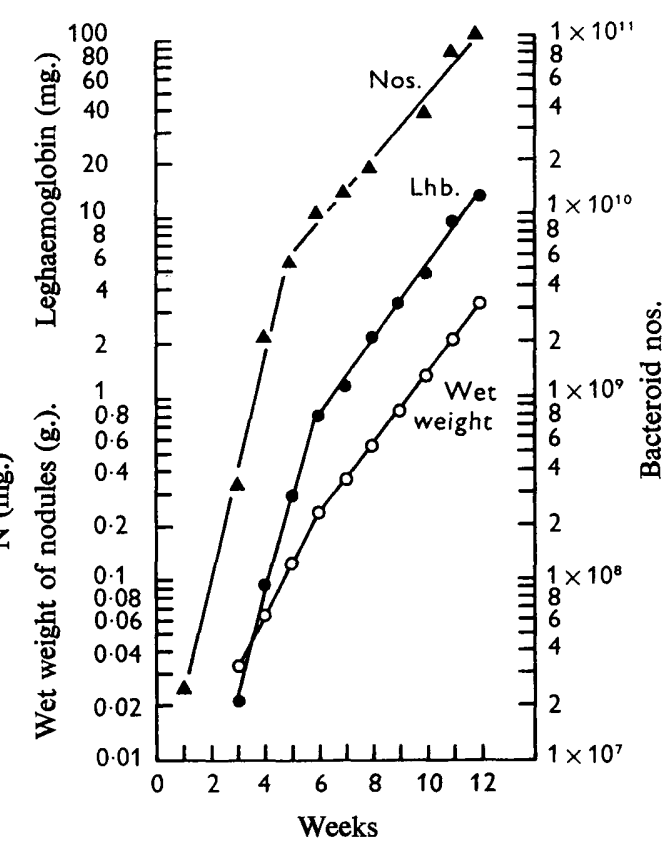

Fig. 2

Fig. 1. Semi-log plot of increase in plant dry weight $(O)$ and total nitrogen $(O)$ as a function of time. All lines of positive slopes are regressions with $P<0.001$.

Fig. 2. Semi-log plot of changes in bacteroid numbers, (A), leghaemoglobin ( $(\mathbf{)})$ and wet weight of nodules $(O)$ per plant. All lines are regressions with $P<0.01$ for the initial parts and $P<0.001$ thereafter.

Leghaemoglobin. Leghaemoglobin was measured in the supernatant from the bacteroids following centrifugation at $25,000 \mathrm{~g}$ for $20 \mathrm{~min}$. at $5^{\circ}$. The solution was diluted in $0.1 \mathrm{M}$-potassium phosphate $(\mathrm{pH} 7 \cdot 1)$, reduced with dithionite, and the leghaemoglobin estimated from its absorption at $555 \mathrm{~m} \mu$ using an extinction coefficient of 7.9 for $1 \%(w / v)$ solution.

\section{RESULTS}

Curves for the increase in dry weight and nitrogen of the plants are shown in Fig. 1. Since the plants were growing in sand, fixation of $\mathrm{N}_{2}$ is apparently contributing to plant growth from about 4 weeks after emergence.

Data for increases in bacteroid numbers, wet weight of nodules, and leghaemoglobin per plant are presented in Fig. 2. The main feature appears to be a discontinuity in the rate of increase of all three parameters at about 5-6 weeks. Apparently this did not 
affect $\mathrm{N}_{2}$ fixation since the nitrogen increase of the whole plants shows no such effect.

The results of the nucleic acid analyses are presented in Fig. 3. There is a marked decline in both RNA and DNA per bacteroid, with a simultaneous fall in protein. It is apparent that the falls in RNA and DNA cease after about 6 weeks, after which relatively constant levels are obtained. A second experiment showed similar falls in RNA, DNA and protein over a period of 5 weeks. The experiment of Fig. 3 was discontinued at 12 weeks with the onset of flowering, in order to avoid possible complications introduced by nodule senescence.

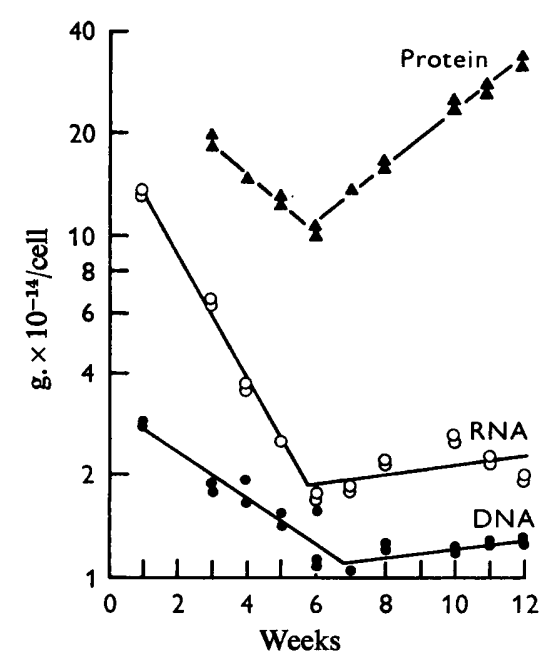

Fig. 3. Semi-log plot of bacteroid protein (A), RNA (O) and DNA (O) as a function of time. All lines of negative slope are regressions with $P<0.001$. Of the lines of positive slope, those for protein and DNA are regressions with $P<0.001$ and 0.05 , respectively.

\section{DISCUSSION}

The morphology of the lupin nodule has been discussed by Kidby \& Goodchild (1966). Because only a collar of nodule tissue is formed from the initial inoculation, it is possible to obtain material of uniform age and development. No senescence is observed in such nodules up to flowering in contrast to the nodules formed by the same rhizobial strain nodulating Ornithopus sativus. This suggests that the changes observed in the bacteroids cannot be due to nodule breakdown but are typical of normal nodule development, a conclusion supported by the consistent increase in nodule weight over the period.

The marked fall in RNA suggests that protein synthesis by bacteroids could be impaired. However, protein per bacteroid increased after 6 weeks, probably as a result of cell enlargement, indicating that protein synthesis was continuing.

The decline in bacteroid DNA has obvious implications for bacteroid viability and appears to confirm observations on the disappearance of nuclear material made by light microscopy (Bergersen, 1955; Heumann, 1952; Schaede, 1941), by chemical analysis (Rautanen \& Saubert, 1955) and by electron microscopy (Dart \& Mercer, 1963). These results are in contrast to those of Bergersen (1958). In view of the relatively short time (about 4 weeks) required for the soybean nodules to reach maximum 
size, compared with the steady increase still proceeding at 12 weeks in the lupin nodule, it seems possible that the changes reported here for nucleic acids may well have taken place very rapidly in the soybean nodules examined. In that case, the relatively constant nucleic acid levels found in soybean bacteroids might correspond to the constant levels found in lupin bacteroids from nodules 6-12 weeks old.

The simultaneous decline in RNA and DNA may, however, be a reflexion of a marked change in growth rate. With Salmonella typhimurium, Schaechter, Maaløe \& Kjeldgaard (1958) found that the function $\log$ (DNA/cell) was linear with the growth rate. Similarly, Lark (1966) showed that the growth rate of Escherichia coli governed its DNA content, with a maximum value some four times the value reported for the non-replicating chromosome (Cairns, 1963). In the lupin nodule, the change in rate of increase of bacteroid numbers seen in Fig. 2 may govern the levels of RNA and DNA found in these cells.

The flat portions of both the RNA and DNA curves are presumably reached when the proportion of actively-dividing rhizobia is small compared to the mass of nonproliferating cells in which decline in RNA and DNA has ceased.

The breaks in slope in the curves at about 6 weeks are at the moment unexplained. However, the fact that the changes in slope are to lower values of nodule parameters suggests a control mechanism on the rate of growth of the nodule relative to that of the plant.

The authors gratefully acknowledge financial support from the Queen Elizabeth II Fellowships Committee of the Australian Prime Minister's Department in the form of a fellowship to one of us (M. J. D.) We are also grateful to Messrs Kidby and Goodchild for making their manuscript available to us, and to Dr C. A. Parker for helpful discussions.

\section{REFERENCES}

Almon, L. (1933). Concerning the reproduction of bacteroids. Zentbl. Bakt. ParasitKde, Abr. II $87,289$.

BERGERSEN, F. J. (1955). The cytology of bacteroids from root nodules of subterranean clover (Trifolium subterraneum L.). J. gen. Microbiol. 13, 411.

BERGERSEN, F. J. (1958). The bacterial component of soybean root nodules; changes in respiratory activity, cell dry weight, and nucleic acid content with increasing nodule age. J. gen. Microbiol. 19 , 312.

BURTON, K. (1956). A study of the conditions and mechanism of the diphenylamine reaction for the colorimetric estimation of deoxyribonucleic acid. Biochem. J. 62, 315.

CaIRns, J. (1963). The chromosome of Escherichia coli. In Synthesis and Structure of Macromolecules. Cold Spring Harb. Symp. quant. Biol. 28, 43.

Chizhiк, G. Ya. (1959). The structure of the root nodule bacteria. Mikrobiologiya, 28, 28. (In Russian, English summary.)

DarT, P. J. \& Mercer, F. V. (1963). Development of the bacteroid in the root nodule of barrel medic (Medicago tribuloides Desr.) and subterranean clover (Trifolium subterraneum L.) Arch. Mikrobiol. 46, 382.

Dawson, R. M. C., Elliott, D. C., Elliott, W. H. \& Jones, K. M. (1959). Data for Biochemical Research, p. 284. Oxford: Clarendon Press.

HeumanN, W. (1952). Physiologische und morphologische Studien an Rhizobium leguminosarum in Knöllchen und auf verschiedenen Nährböden. Ber. dt. bot. Ges. 65, 229.

KIDBY, D. K. \& GoodchILD, D. J. (1966). Host influence on ultra-structure in nodules of Lupinus luteus and Ornithopus sativus. J. gen. Microbiol. 45, 147.

LARK, C. (1966). Regulation of deoxyribonucleic acid synthesis in Escherichia coli; dependence on growth rates. Biochim. biophys. Acta 119, 517. 
Oliver, I. T. \& Blumer, W. F. C. (1964). Metabolism of nucleic acids during liver maturation in the neonatal rat. Biochem. J. 91, 559.

PARKER, C. A. \& OAKLeY, A. E. (1963). Nodule bacteria for two species of serradella-Ornithopus sativus and Ornithopus compressus. Aust. J. exp. Agric. Anim. Husb. 3, 9.

Rautanen, N. \& SaUbert, S. (1955). Root nodules of leguminous plants. A chemical study. Acta chemica fenn. $28 \mathrm{~B}, 66$.

Schaechter, M., MaAløe, O. \& KJeldgaARd, N. O. (1958). Dependency on medium and temperature of cell size and chemical composition during balanced growth of Salmonella typhimurium. J. gen. Microbiol. 19, 592.

ScHAEDE, R. (1941). Untersuchungen in den Wurzelknöllchen von Vicia faba und Pisum sativum. Beitr. Biol. Pfl. $27,165$.

VolkIN, E. \& CoHN, W. E. (1954). In Methods of Biochemical Analysis. ed. by D. Glick, p. 287. New York: Interscience Publishers. 